\title{
Erosion Process of Light-cured and Conventional Glass Ionomer Cements in Citrate Buffer Solution
}

\author{
Fazhang GAO, Shigeki MATSUYA ${ }^{1}$, Michio OHTA ${ }^{1}$ and Jianzhong ZHANG
}

Department of Prosthodontics, School of Stomatology,

Shanghai Second Medical University, Shanghai 200011, China.

${ }^{1}$ Department of Dental Materials Engineering, Faculty of Dentistry,

Kyushu University, Fukuoka 812-82, Japan.

Received July 11, 1997/Accepted September 8, 1997

\begin{abstract}
The aim of this study was to clarify the erosion behavior of light-cured glass ionomer cement. One light-cured glass ionomer cement and two conventional chemically-cured glass ionomer cements were immersed in citric acid buffer solutions of $\mathrm{pH} 4$ and $\mathrm{pH}$. Fluoride release was almost the same in both types of cements, irrespective of $\mathrm{pH}$. The amounts of other species eluted, such as $\mathrm{Al}, \mathrm{Sr}, \mathrm{Si}$ and $\mathrm{P}_{2} \mathrm{O}_{5}$ were smaller in the light-cured glass ionomer cement than in the conventional ones at $\mathrm{pH} 4$. The amounts of species eluted at $\mathrm{pH} 6$ were almost the same in both types of cement. Dissolution of the light-cured cement in $\mathrm{pH} 4$ solution was controlled by the diffusion of the eluted species in the cement matrix. On the other hand, dissolution of the conventional cements was controlled by both diffusion and surface reaction. The surface features of the cements after erosion corresponded well to the dissolution mechanism. In $\mathrm{pH} 6$ solution, dissolution of the cements was mainly controlled by diffusion of the species in the cement.
\end{abstract}

Key words: Light-cured glass ionomer cement, Erosion, Citric acid

\section{INTRODUCTION}

Since glass ionomer cements possess many characteristics of an ideal restorative material, the use of glass ionomer cements has grown since their introduction in the 1970s. However, the conventional glass ionomer cement has some disadvantages, such as a sensitivity to moisture during initial hardening, a prolonged setting time that restricts finishing and polishing for about 24 hours, a rough surface texture etc ${ }^{1,2}$. Recently, several new light-cured glass ionomer cements have been developed in an effort to overcome the disadvantages of the conventional materials ${ }^{3-6}$. The manufacturers have claimed that superior mechanical and physical properties are achieved rapidly after placement as a result of the photopolymerization.

In an oral environment, both dissolution of elements and erosion of the non-soluble components of material occur. There are many studies on the release of fluoride and other elements from cement in vitro ${ }^{7-12)}$ and in vivo ${ }^{13,14)}$. The mechanism for erosion of conventional glass ionomer cements have been discussed ${ }^{15-18)}$. Fluoride release from light-cured glass ionomer cements has also been reported ${ }^{19-21)}$. Mitra ${ }^{19)}$ described fluoride release from a light-cured glass ionomer cement in a phosphate buffer at $\mathrm{pH}$ 
6.8 occurring through a diffusion mechanism. Forss ${ }^{22)}$ reported the release of other elements as well as fluoride from light-cured glass ionomer cements in de-ionized water and $0.01 \mathrm{~mol} / \mathrm{L}$ lactic acid at $\mathrm{pH} 4$. Forss, however, did not discuss the dissolution mechanism of the cements.

In the present study, various elements eluted in $0.01 \mathrm{~mol} / \mathrm{L}$ citric acid buffers from both conventional and light-cured glass ionomer cements were quantitatively determined. The dissolution mechanism and the erosion behavior of those cements were compared.

\section{MATERIALS AND METHODS}

Table 1 lists the two conventional (FIC, HYC) and one light-cured (FIL) glass ionomer cements used in this study. The cement powder was chemically analyzed after being dissolved in $6 \mathrm{~N} \mathrm{HCl}$ or $0.5 \mathrm{~N} \mathrm{HCl}$, using the methods reported by $\mathrm{Cook}^{23)}$ and Hattab ${ }^{24}$. Table 2 shows the composition of the cement powder. The content of $\mathrm{Si}$ is the one soluble form. The powder and liquid for each cement were mixed according to the manufacturers' instructions. After the cement paste was poured into a Teflon ring placed on a flat glass plate, a piece of nylon wire $\left(0.3 \mathrm{~mm}^{\phi}\right)$ was inserted into the paste. This was covered and pressed with another glass plate. The light-cured glass ionomer cement was irradiated through the glass plate from both sides each for $10 \mathrm{~s}$ with a light curing unit (LIGHTEL, DP-075, Morita Co. Ltd., Tokyo, Japan), and the cement disk (10 mm in diameter X $2 \mathrm{~mm}$ thick) was then aged in an oven maintained at $37^{\circ} \mathrm{C}$ and $100 \%$ relative humidity. One hour after being mixed, each cement disk was suspended by the nylon wire in a polyethylene bottle containing $50 \mathrm{~mL}$ of $0.01 \mathrm{~mol} / \mathrm{L}$ citric acid buffer solutions at either $\mathrm{pH} 4$ or 6 . The polyethylene bottle was set in an incubator maintained at $37^{\circ} \mathrm{C}$ and shaken at $20 \mathrm{~mm}$ amplitude and $2 \mathrm{~Hz}$. After the required time had elapsed from the start of immersion, the cement disk was taken out of the solution, pressed with filter paper, and

Table 1 Cements used in this study

\begin{tabular}{c|c|c|c}
\hline \multicolumn{1}{c|}{ Cement } & Type & Code & P/L ratio \\
\hline Fuji Ionomer Type II ${ }^{*}$ & Conventional & FIC & 2.7 \\
\hline HY-BOND GLASIONOMER-F** & Conventional & HYC & 2.5 \\
\hline Fuji Ionomer Type II LC & Light-cured & FIL & 3.0 \\
\hline \multicolumn{2}{r}{${ }^{*}$ GC Corp., Tokyo, Japan, ${ }^{* *}$ Shofu Inc., Kyoto, Japan }
\end{tabular}

Table 2 Composition of the cement powder ( $\mathrm{mg} / \mathrm{g}$-powder)

\begin{tabular}{c|c|c|c|c|c|c}
\hline Cement & $\mathrm{Al}$ & $\mathrm{Ca}$ & $\mathrm{Sr}$ & $\mathrm{Si}^{*}$ & $\mathrm{~F}$ & $\mathrm{P}_{2} \mathrm{O}_{5}$ \\
\hline FIC & 142.9 & - & 190.9 & 8.67 & 77.9 & 43.4 \\
\hline HYC & 144.1 & 78.3 & 1.69 & 24.4 & 96.5 & 71.4 \\
\hline FIL & 110.9 & - & 186.1 & 5.69 & 101.5 & 14.9 \\
\hline
\end{tabular}


transferred into another $50 \mathrm{~mL}$ of fresh solution. The solution was changed at 30 min, $1 \mathrm{~h}, 2 \mathrm{~h}, 4 \mathrm{~h}, 8 \mathrm{~h}, 24 \mathrm{~h}$ and $48 \mathrm{~h}$. Total immersion periods were $48 \mathrm{~h}$ at $\mathrm{pH} 4$ and $72 \mathrm{~h}$ at pH6. Those solutions were chemically analyzed. Fluoride (F) concentration was determined by an ion-specific electrode (Model 94-09, Orion Research, Cambridge, MA). Phosphate $\left(\mathrm{P}_{2} \mathrm{O}_{5}\right)$ and $\mathrm{Si}$ were determined by spectrophotometry (U-best 50, Jasco, Tokyo, Japan) using the molybdenum blue and the silicomolybdic acid methods ${ }^{25)}$, respectively. Aluminum ( $\mathrm{Al}$ ) and calcium ( $\mathrm{Ca}$ ) were analyzed by atomic absorption spectroscopy (AA640-13, Shimadzu, Kyoto, Japan) and strontium (Sr) by flame emission spectroscopy. The amount of each species eluted from the cement was expressed as a cumulative weight per unit surface area. Each immersion experiment was repeated twice and the the cumulative weights were averaged. The free surfaces of the cement disks before and after immersion were observed using a scanning electron microscope (JSM 5400LV, Jeol, Tokyo, Japan) after gold sputter-coating.

\section{RESULTS}

Table 3 shows the cumulative amount of each species eluted per a unit surface area of the cements into $\mathrm{pH} 4$ solution (CA4) and $\mathrm{pH} 6$ solution (CA6) for $48 \mathrm{~h}$ and $72 \mathrm{~h}$, respectively. The elution of $\mathrm{Ca}$ from FIC and FIL in both solutions and that of $\mathrm{Sr}$ from HYC in the CA6 solution were too small to be determined; their content in the cements being very small, as shown in Table 2. The data in Table 3 are the average of two experiments. Reproducibility of the data for CA4 was good, with a difference of less than $20 \%$ except for $\mathrm{Si}$. However, the elution of species at $\mathrm{pH} 6$ was quite small and the data for CA6 showed some variation from differences in value of paired measurements reaching about $60 \%$. Reproducibility of the data seemed to depend on the elements concerned. The amounts of species eluted were larger in the lower $\mathrm{pH}$ solution. The amounts of species eluted from HYC seemed to be largest and that from the light-cured type glass ionomer cement, FIL, to be smallest in CA4 solution. However, the amounts of species eluted in CA6 solution were almost the same in all three cements.

Figs. 1 (a) and 1 (b) show plots of the cumulative mass of Al eluted from the ce-

Table 3 Total amounts of species $\left(\mathrm{mg} / \mathrm{cm}^{2}\right)$ eluted from the cements in the citrate buffer solutions, CA4 for $48 \mathrm{~h}$ and CA6 for $72 \mathrm{~h}$

\begin{tabular}{c|c|c|c|c|c|c|c}
\hline Solution & Cement & $\mathrm{Al}$ & $\mathrm{Ca}$ & $\mathrm{Sr}$ & $\mathrm{Si}$ & $\mathrm{F}$ & $\mathrm{P}_{2} \mathrm{O}_{5}$ \\
\hline \multirow{3}{*}{$\begin{array}{c}\text { CA4 } \\
(\mathrm{pH} 4)\end{array}$} & FIC & 1.76 & - & 1.19 & 3.55 & 3.12 & 0.48 \\
\cline { 2 - 8 } & HYC & 3.85 & 2.30 & $0.03^{*}$ & 7.39 & 5.25 & 1.59 \\
\cline { 2 - 8 } & FIL & 0.88 & - & 0.74 & 1.36 & 2.75 & 0.07 \\
\hline \multirow{3}{*}{$\begin{array}{c}\text { CA6 } \\
(\mathrm{pH} 6)\end{array}$} & FIC & 0.10 & - & 0.31 & 0.16 & 0.55 & 0.10 \\
\cline { 2 - 8 } & HYC & 0.14 & 0.30 & - & 0.07 & 0.31 & 0.09 \\
\cline { 2 - 8 } & FIL & 0.15 & - & 0.40 & 0.04 & 0.45 & 0.15 \\
\hline
\end{tabular}



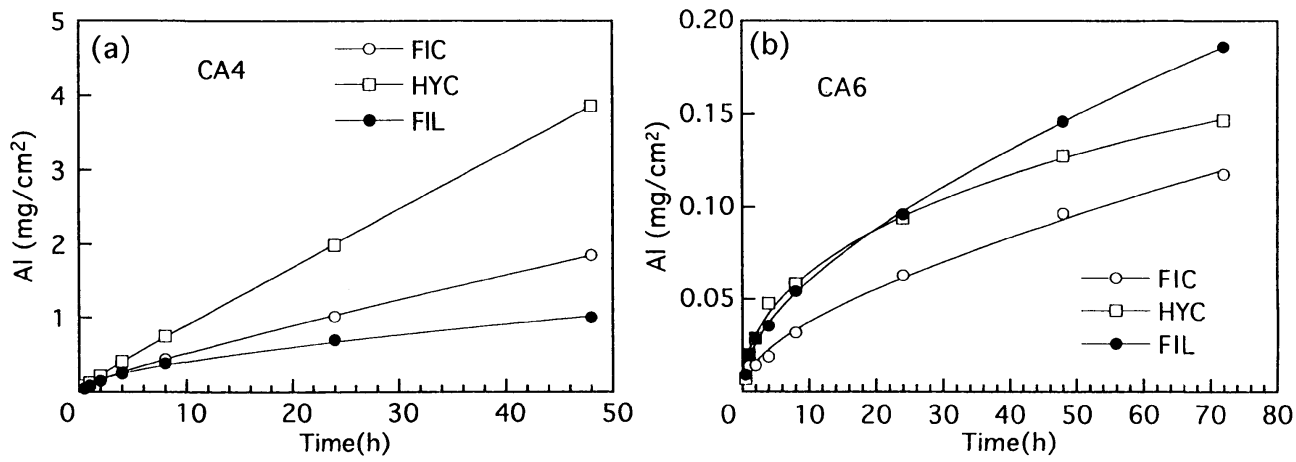

Fig. 1 Plots of the cumulative mass of $\mathrm{Al}$ eluted from three cement against time in the citrate buffer solutions

(a) in CA4 ( $\mathrm{pH} \mathrm{4)}$; (b) in CA6 ( $\mathrm{pH} 6)$.
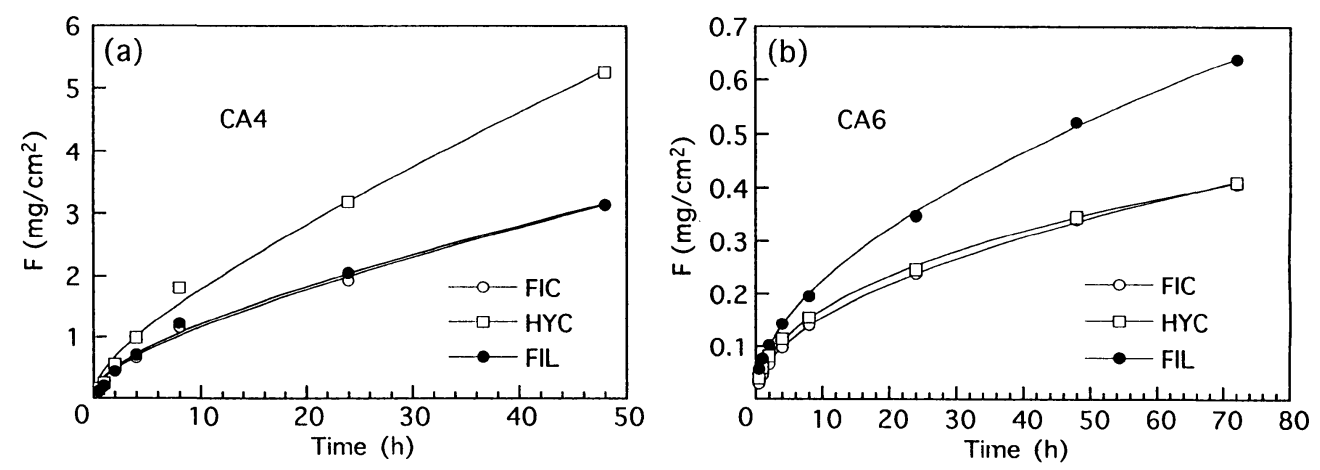

Fig. 2 Plots of the cumulative mass of $\mathrm{F}$ eluted from three cements against time in the citrate buffer solutions

(a) in $\mathrm{CA} 4(\mathrm{pH} 4)$; (b) in $\mathrm{CA} 6(\mathrm{pH} 6)$.

ments against time in the $\mathrm{CA} 4$ and $\mathrm{CA} 6$ solutions, respectively. The cumulative amount of $\mathrm{Al}$ eluted from HYC and FIC increased linearly with time in the CA4 solution. Ca eluted from $\mathrm{HYC}$ and $\mathrm{P}_{2} \mathrm{O}_{5}$ eluted from FIL in the CA4 solution also showed a similar changes, although they are not shown here. On the other hand, the elution rate of FIL gradually decreased with time in the CA4 solution. This tendency was also observed with all of the cements in the CA6 solution.

Figs. 2 (a) and 2 (b) show plots of the cumulative mass of $\mathrm{F}$ eluted from cements against time in the $\mathrm{CA} 4$ and $\mathrm{CA} 6$ solutions, respectively. The elution rate decreased gradually with time in both solutions. Other species, such as $\mathrm{Sr}, \mathrm{Ca}, \mathrm{P}_{2} \mathrm{O}_{5}$ and $\mathrm{Si}$, behaved in a same way, except for the cases of $\mathrm{Ca}$ from $\mathrm{HYC}$ and $\mathrm{P}_{2} \mathrm{O}_{5}$ from FIL in the CA4 solution, as described above.

Fig. 3 shows the free surface of FIC, HYC and FIL disks before and after immersion in CA4 for $48 \mathrm{~h}$ and in CA6 for $72 \mathrm{~h}$. The surface characteristics of disks for each cements are quite different in the CA4 and CA6 solutions. The surfaces of the 

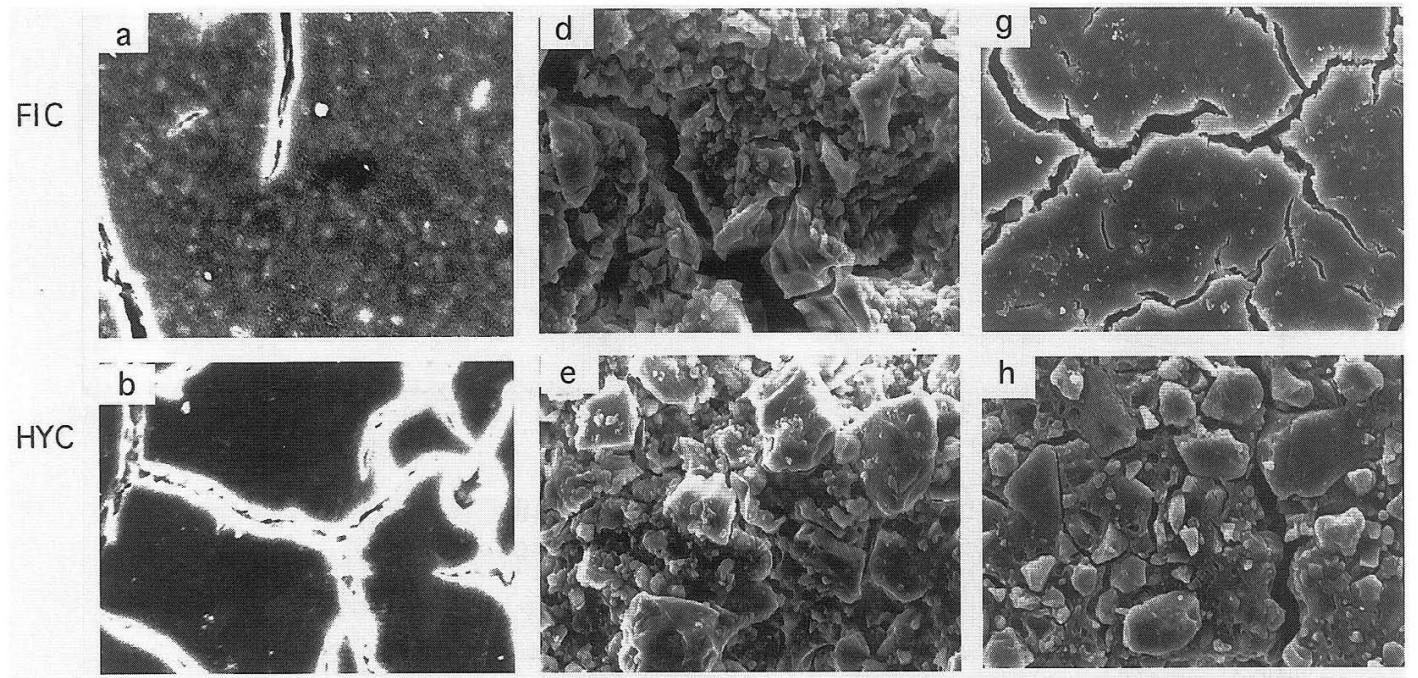

FIL

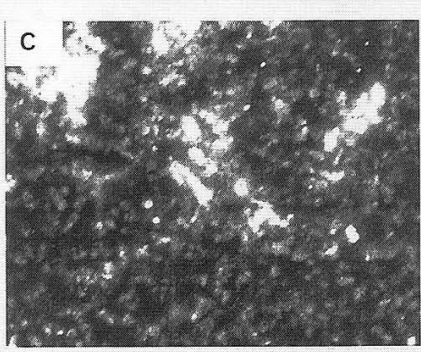

before immersion

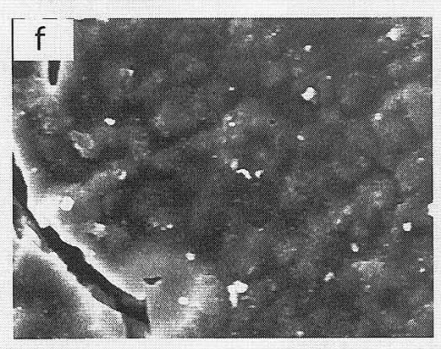

$\mathrm{pH} 4$

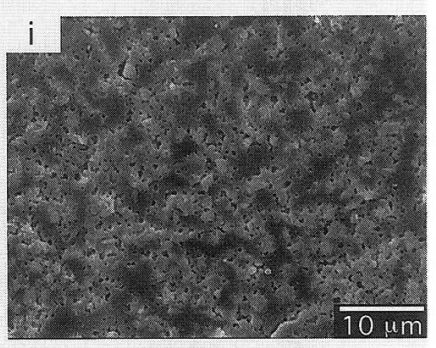

$\mathrm{pH} 6$

Fig. 3 SEM photographs of the cement surfaces before ( $a, b, c)$ and after immersion in the citrate buffer solution at $\mathrm{pH} 4(\mathrm{~d}, \mathrm{e}, \mathrm{f})$ and at $\mathrm{pH} 6(\mathrm{~g}, \mathrm{~h}, \mathrm{i})$.

cements before immersion were relatively smooth, the cement having been hardened between two parallel glass plates. $\Lambda \mathrm{fter}$ immersion in CA4, the two conventional glass ionomer cements, FIC and HYC, had rough surfaces, with many cement particles exposed (Fig. 3 d, e). However, the light-cured type, FIL had a rugged surface and the cement particles were not seen on the surface (Fig. $3 \mathrm{f}$ ). In CA6 solution, the surface after immersion had different features depending on the cements. With FIC the surface was very smooth, although there were large cracks due to the heat at preparation for the SEM sample by Au sputter-coating (Fig. $3 \mathrm{~g}$ ). HYC showed the same surface feature as seen with CA4 solution (Fig. 3 h). Many small voids were seen on the surface of FIL after immersion (Fig. 3 i).

\section{DISCUSSION}

The amounts of species eluted from cements.

As shown in Table 3, with CA4, elution of all species except for $\mathrm{F}$ from the light- 
cured glass ionomer cement, FIL, was less than that from the conventional glass ionomer cements, FIC and HYC. Less elution of Sr from HYC in CA4 was the result of its low content in the original cement powder, as shown in Table 2. On the other hand, elution of all species from the cements in CA6 were roughly the same. FIL eluted a considerable amount of $\mathrm{Al}$ and $\mathrm{Sr}$ into the solutions. This suggests that both types of cement were equally susceptible to erosion. Also shown in Table 3, the elution of each species from the cements in CA4 was more than that in CA6, except for $\mathrm{P}_{2} \mathrm{O}_{5}$ from FIL. This result suggests that the light-cured glass ionomer cement also had high sensitivity to acid solutions.

It is interesting that the amount of $\mathrm{F}$ eluted from FIL was almost equal to that from FIC in CA4 solution, although the elution of other species was less in FIL. It has been reported that $\mathrm{F}$ release was almost equivalent between conventional and light-cured glass ionomer cements ${ }^{21)}$. Although a number of studies have been made on $\mathrm{F}$ release from glass ionomer cements ${ }^{7-22)}$, the mechanism has not been clarified yet. However, the availability of $\mathrm{F}$ is determined by its chemical form and distribution in the cement, and these parameters are influenced by the setting reaction. It was reported that $\mathrm{F}^{-}$ions in the matrix require a long time to form insoluble complexes ${ }^{26)}$. The release of $\mathrm{F}$ thus decreases with increasing aging time, and Davis et al. ${ }^{12}$ reported that the fluoride release was dependent on the maturity of the cement matrix. On the other hand, Bourke et al. ${ }^{27)}$ found that a light-cured glass ionomer cement had two distinct phases to its setting reaction; light activation resulted in a rapid initial set, after which a slower acid-base reaction continued in the absence of light. In this study, the light-cured glass ionomer cement might have been sufficiently aged, resulting in the elution of large amounts of $\mathrm{F}$. Moreover, Kuhn and Wilson ${ }^{16)}$ suggested that if the concentration of leachable ions in a gel matrix decreased to a lower level than that in surrounding solution, ions would diffuse back to the gel matrix of the cement. $\mathrm{F}^{-}$ions might then exchange with $\mathrm{OH}^{-}$ions to form less soluble fluoride compounds. This theory might also explain the fact that there was no difference in fluoride release between the conventional and the light-cured glass ionomer cements.

Kinetics of dissolution.

Fukazawa et al. ${ }^{18)}$ reported that the amount of species eluted from conventional chemically-cured glass ionomer cements into organic-acid buffer solutions was welldescribed by the equation.

$$
\mathrm{M}_{\mathrm{t}}=\mathrm{kt}^{\mathrm{n}}
$$

where $\mathrm{Mt}$ is the amount of species eluted from the cement at time, $\mathrm{t}$, and $\mathrm{k}$ and $\mathrm{n}$ are constants. In this study, irrespective of the type of cement, the observed changes in amounts of elution fitted Eq.1, with $\mathrm{n}$ between 0.5 and 1 . According to Kuhn and Wilson $^{16)}$ and Fukazawa et al. ${ }^{17)}$, when $\mathrm{n}$ was 0.5 in Eq.1, the diffusion in cement matrix controlled the elution of species into solution, and when $n$ was 1 the surface reaction controlled the dissolution. As already described, the value of $\mathrm{n}$ was usually between 0.5 and 1 , showing that both of the processes, diffusion and surface reaction, were involved in the dissolution of the cement. However, it is difficult to evaluate the 
relative extent by which the processes controlled the dissolution.

Fukazawa et al. ${ }^{17)}$ also reported that the dissolution of glass ionomer cement was well-described by Eq.2,

$$
\mathrm{M}_{\mathrm{t}}=\mathrm{at}^{1 / 2}+\mathrm{bt}
$$

where $\mathrm{a}$ and $\mathrm{b}$ are constants. Eq. 2 was originally proposed as an empirical relationship to explain the water-leaching of $\mathrm{Na}$ from a $15 \% \mathrm{Na} 2 \mathrm{O}-85 \% \mathrm{SiO}$ glass $^{28)}$. In the equation, the two processes involved in the dissolution of cement, diffusion and surface reaction, could be thoought of as the right hand first and second terms, respectively. The ratio, $a / b$ should represent the preferences of the two processes in the dissolution. Eq.2 was also applied successfully to the dissolution process of zinc polycarboxylate ${ }^{29)}$ and zinc phosphate cements ${ }^{30)}$. The amount of each species eluted from the cements in this study was consistent by a least-squares calculation using Eq.2. Table 4 shows the obtained values of $a, b$, correlation coefficient $r$, and $a / b$ for the cements. The value of $b$ eventually reached minus one. However, as these values are extremely small compared with the value of a, they can be ignored (shown as "-" in Table 4). In CA4 solution, the a/b ratio for $\mathrm{Al}$, which is one of the main components of the cement powder and contributes the matrix formation, is smaller in the conventional glass ionomer cements (FIC and HYC) than in the light-cured type cement (FIL). Dissolution of the conventional glass ionomer cements in CA4 was controlled by both diffusion and surface reaction. On the other hand, the larger $\mathrm{a} / \mathrm{b}$ value for FIL (except for $\mathrm{P}_{2} \mathrm{O}_{5}$ ) suggest that the first term in Eq.2 greatly contributs to the dissolution. Dissolution of the light-cured type cement was therefore mainly controlled by diffusion.

Table 4 also shows that the values of $\mathrm{a} / \mathrm{b}$ for HYC were smaller than those for FIC. This fact suggests that the contribution of the surface reaction to dissolution

Table 4 Values of $a, b, a / b$ and correlation coefficient, $r$ in eq. $2, M_{t}\left(\mathrm{mg} / \mathrm{cm}^{2}\right)=a t^{1 / 2}+b t$

\begin{tabular}{c|c|c|c|c|c|c|c|c|c|c|c|c}
\hline $\mathrm{CA} 4(\mathrm{pH} 4)$ & \multicolumn{4}{|c|}{$\mathrm{FIC}$} & \multicolumn{4}{c|}{$\mathrm{HYC}$} & \multicolumn{4}{c}{$\mathrm{FIL}$} \\
\hline & $\mathrm{a}$ & $\mathrm{b}$ & $\mathrm{a} / \mathrm{b}$ & $\mathrm{r}$ & $\mathrm{a}$ & $\mathrm{b}$ & $\mathrm{a} / \mathrm{b}$ & $\mathrm{r}$ & $\mathrm{a}$ & $\mathrm{b}$ & $\mathrm{a} / \mathrm{b}$ & $\mathrm{r}$ \\
\hline $\mathrm{Al}$ & 0.0747 & 0.0278 & 2.69 & 1.000 & 0.0527 & 0.0728 & 0.72 & 1.000 & 0.1102 & 0.0053 & 20.7 & 0.997 \\
$\mathrm{Ca}$ & & & & & 0.0623 & 0.0385 & 1.62 & 0.999 & & & & \\
$\mathrm{Sr}$ & 0.0881 & 0.0142 & 6.19 & 1.000 & & & & & 0.0906 & 0.0042 & 21.5 & 0.997 \\
$\mathrm{Si}$ & 0.335 & 0.0445 & 7.53 & 0.999 & 0.599 & 0.0852 & 7.03 & 0.999 & 0.352 & - & - & 0.999 \\
$\mathrm{~F}$ & 0.294 & 0.0231 & 12.7 & 0.997 & 0.394 & 0.153 & 2.57 & 0.996 & 0.319 & 0.0198 & 16.1 & 0.996 \\
$\mathrm{P}_{2} \mathrm{O}_{5}$ & 0.0273 & 0.0062 & 4.41 & 0.997 & 0.142 & 0.0109 & 13.0 & 0.991 & 0.0020 & 0.0014 & 1.44 & 0.996 \\
\hline
\end{tabular}

\begin{tabular}{c|c|c|c|c|c|c|c|c|c|c|c|c}
\hline CA6 (pH 6) & \multicolumn{4}{|c|}{ FIC } & \multicolumn{4}{c|}{ HYC } & \multicolumn{4}{c}{ FIL } \\
\hline & $\mathrm{a}$ & $\mathrm{b}$ & $\mathrm{a} / \mathrm{b}$ & $\mathrm{r}$ & $\mathrm{a}$ & $\mathrm{b}$ & $\mathrm{a} / \mathrm{b}$ & $\mathrm{r}$ & $\mathrm{a}$ & $\mathrm{b}$ & $\mathrm{a} / \mathrm{b}$ & $\mathrm{r}$ \\
\hline $\mathrm{Al}$ & 0.0104 & 0.0004 & 23.5 & 0.998 & 0.0221 & - & - & 0.997 & 0.0173 & 0.0005 & 31.5 & 0.999 \\
$\mathrm{Ca}$ & & & & & 0.0566 & - & - & 0.999 & & & & \\
$\mathrm{Sr}$ & 0.0418 & - & - & 0.997 & & & & & 0.2834 & 0.0010 & 272 & 0.999 \\
$\mathrm{Si}$ & 0.0008 & - & - & 0.997 & 0.0072 & 0.0003 & 21.8 & 0.994 & 0.0071 & - & - & 0.998 \\
$\mathrm{~F}$ & 0.0491 & - & - & 1.000 & 0.0571 & - & - & 1.000 & 0.0688 & 0.0008 & 86.3 & 1.000 \\
$\mathrm{P}_{2} \mathrm{O}_{5}$ & 0.0293 & - & - & 0.997 & 0.0524 & - & - & 0.996 & 0.0464 & 0.0014 & 33.1 & 0.987 \\
\hline
\end{tabular}


was larger in HYC. Stability of the cement matrix is different among the cements because the polymeric acids in the cement liquids are crosslinked by $\mathrm{Al}^{3+}$ and $\mathrm{Ca}^{2+}$ (or $\mathrm{Sr}^{2+}$ ) ions in a different way. According to the patent information, the liquid component of FIC seems to be a copolymer of acrylic acid and maleic or itaconic acid ${ }^{31}$, while that of $\mathrm{HYC}$ to be a copolymer of acrylic acid and 3-butene-1,2,3tricarboxylic $\operatorname{acid}^{32)}$. Further study on the structure and chemical stability of the cement matrix of the polymeric acid salts - which contributes the hardening of the cement- will be necessary.

For all the cements, the dissolution of each element was controlled mainly by diffusion in CA6 solution. It is noted that the values of "a" for all elements tended to be larger in the light-cured type, FIL, than the conventional glass ionomer, FIC. This means that diffusion through the matrix was larger in FIL. It has been reported that water absorption was higher in light cured type glass ionomer cements than in conventional glass ionomer cements ${ }^{33}$. This is one of the reasons why diffusion was promoted in the matrix of FIL. Moreover, it was suggested that the diffusion through a water-absorbed resin matrix was much faster than through a matrix consisting of the polymeric acid salt gels contained in the conventional glass ionomer cement. The diffusion of the matrix forming cations was thus retarded by the interaction with the carboxyl group of the polymeric acid.

\section{Change in the surface structure of the cement by erosion.}

The SEM observation revealed that the surface characteristics of the light-cured cement disks were quite different to those of the two conventional cements after immersion in the solutions. With FIC and HYC immersed in CA4, the cement matrix and glass particles were simultaneously dissolved and the surface became rough (Fig. $3 \mathrm{~d}$, e). Many glass particles were exposed on the cement surfaces. The citric acid used in this study forms stable soluble complexes with $\mathrm{Al}^{3+}$ and $\mathrm{Ca}^{2+}\left(\right.$ or $\mathrm{Sr}^{2+}$ ) ions ${ }^{8)}$. In CA4 solution with a lower $\mathrm{pH}$, the driving force of the dissolution is both $\mathrm{H}^{+}$ion attack and the complex formation of those cations in the cement. The extent of matrix erosion was determined by the difference between the stability of the crosslinking of carboxylate ions by $\mathrm{Al}^{3+}$ or $\mathrm{Ca}^{2+}\left(\right.$ or $\mathrm{Sr}^{2+}$ ) in the gel matrix and the citrate complexes. The surfaces of FIC and HYC showed that the gel matrix areas of the cements were eroded through the citrate complex formation. The matrix of HYC seemed to be eroded more severely than that of FIC. This fact explains smaller $a / b$ value in HYC, which corresponds to a larger contribution of the surface reaction to the dissolution process. On the other hand, with FIL immersed in CA4, the glass particles, the cement matrix and the resin matrix were also eroded by layers, resulting in some tubercles which seemed to be the glass particles covered by polymer matrix (Fig. $3 \mathrm{f}$ ). The resin matrix was thus highly stable to the acid attack, resisting even the citric acid which would otherwise form stable complexes as seen in the conventional glass ionomer cements. This fact conforms that the dissolution was controlled by diffusion through the resin matrix as described above.

The surface of FIC immersed in CA6 solution was relatively smooth, showing no 
evidence of matrix erosion (Fig. $3 \mathrm{~g}$ ). The matrix of HYC seemed to be less stable than that of FIC as shown in Fig. $3 \mathrm{~g}$ and $\mathrm{h}$, probably because the polymeric acid in the liquid components were different. With FIL at $\mathrm{pH} 6$, the resin matrix did not erode and the dissolution was initiated at the weaker points, that is, the salt gel matrix and/or the unreacted glass particles. Thus, many small voids were left on the surface of FIL as shown in Fig. 3 i. A similar structure was also observed on the surface of zinc phosphate or zinc polycarboxylate cements immersed in an acetic acid solution with weak complexing ability ${ }^{34,35)}$.

\section{CONCLUSION}

The cumulative amount $\left(\mathrm{M}_{\mathrm{t}}\right)$ of species eluted from the glass ionomer cement in $0.01 \mathrm{M}$ citrate buffer at $\mathrm{pH} 4$ and 6 was well expressed by the equation $\mathrm{M}_{\mathrm{t}}=a \mathrm{t}^{1 / 2}+\mathrm{bt}$. The first right-hand term relates to diffusion, and the second to surface reaction. For the light-cured glass ionomer cement, the dissolution rate was controlled by diffusion of the eluted species through the resin matrix at both pHs. For the conventional glass ionomer cements, both diffusion and surface reaction controlled the dissolution at $\mathrm{pH} \mathrm{4}$, but diffusion was predominant at $\mathrm{pH} 6$. The extent of matrix erosion reflected the nature of the cement matrices. Even in the conventional glass ionomer cements, the stability of the matrix seemed to determine the erosion features of the surface.

\section{REFERENCES}

1) Craig, R. C.: Restorative dental materials 8th ed. CV Mosby, St Louis, 1989, pp.284-286.

2) Phillips, R. W.: Skinner's science of dental materials. 9th ed., WB Sounders, Philadelphia, 1991, pp.451-461.

3) Hammesfahr, P. D.: Technical Perspectives. Milford, Del, LD Caulk, 1992, pp.1-3.

4) Christensen, G.: Glass ionomer-resin restorations. CA Newsletter March 1992, pp.1-2.

5) Hinoura, K., Miyazaki, M. and Onose, H.: Dentin bond strength of light-cured glassionomer cements, J Dent Res $70: 1542-1544,1991$.

6) Mciaghren, R. A., Retief, D. H., Bradley, E. I. and Denys, F. R.: Shear bond strength of light-cured glass ionomer to enamel and dentin, J Dent Res 69:40-45, 1990.

7) Swartz, M. L., Phillips, R.W. and Clark, H. E.: Long-term F Release from Glass Ionomer Cements, $J$ Dent Res 63(2): 158-160, 1984.

8) Matsuya, S., Matsuya, Y., Yamamoto, Y. and Yamane, M.: Erosion process of a glass ionomer cement in organic acids solution, Dent Mater $J 3: 210-219,1984$.

9) Forsten, L.: Fluoride release and uptake by glass ionomers, Scand $J$ Dent Res 99 : 241245, 1991.

10) DeSchepper, E. J., Berry III, E. A., Cailleteau, J. G. and Tate, W. H.: A comparative study of fluoride release from glass-ionomer cements, Quintessence 22(3):215-220, 1991.

11) Andersson, Ö. H. and Dahl, J.E.: Aluminium release from glass ionomer cements during early water exposure in vitro, Biomater $15: 882-888,1994$.

12) Davies, E. H., Sefton, J. and Wilson, A. D.: Preliminary study of factors affecting the fluoride release from glass-ionomer cements, Biomater 14(8):636-639, 1993.

13) Hatibovic-Kofman, S. and Koch, G.: Fluoride release from glass ionomer cement in vivo and in vitro, Swed Dent $J 15: 253-258,1991$.

14) Hattab, F. N., El-Mowafy, O. M., Salem, N.S. and El-Badrawy, W. A. G.: An in vivo 
study on the release of fluoride from glass-ionomer cement, Quintessence Int 22(3):221$224,1991$.

15) Wilson, A. D., Groffman, D. M. and Kuhn, A.T.: The release of fluoride and other chemical species from a glass-ionomer cement, Biomater 6 : 431-433, 1985.

16) Kuhn, A. T. and Wilson, A. D.: The dissolution mechanism of silicate and glass-ionomer dental cements, Biomater $6: 378-382,1985$.

17) Fukazawa, M. Matsuya, S. and Yamane, M.: The Mechanism for erosion of glassionomer cement in an acidic buffer solution, J Dent Res 66(12) : 1770-1774 ,1987.

18) Fukazawa, M. Matsuya, S. and Yamane, M.: The Mechanism for erosion of glassionomer cements in organic-acid buffer solutions, J Dent Res 69:1175-1179 , 1990.

19) Mitra, S. B.: In vitro Fluoride release from a light-cured glass-ionomer liner/base, $J$ Dent Res 70(1) : 75-78, 1991.

20) Hörsted-Bindslev, P. and Larsen, M. J.: Release of fluoride from light cured lining materials, Scand J Dent Res 99 : 86-88, 1991.

21) Momoi, Y. and McCabe, J.F.: Fluoride release from light-activated glass ionomer restorative cements, Dent Mater 9 : 151-154, 1993.

22) Forss, H.: Release of fluoride and other elements from light-cured glass ionomers in neutral and acidic conditions, $J$ Dent Res 72(8) : 1257-1262, 1993.

23) Cook, W. D.: Degradative analysis of glass ionomer polyelectrolyte cements, J Biomed Mater Res $17: 1015,1983$.

24) Hattab, F. N.: Direct determination of fluoride in selected dental materials, Dent Mater $3: 67-70,1987$.

25) The Chemical Society of Japan.: Shin Jikken Kagaku Kouza Vol.9 Bunseki Kagaku I, Maruzen Co. Tokyo, Japan, 1975, p.117, pp.190-191. (in Japanese)

26) Crisp, S., Pringuer, M. A., Wardleworth, D. and Wilson, A. D.: Reaction in glass ionomer cements: II. An infrared spectroscopic study, J Dent Res 53 : 1414-1419, 1974.

27) Bourke, A.M., Walls, A.W., McCabe, J.F.: Light-activated glass polyalkenoate (ionomer) cements: The setting reaction., J Dent $20: 115-120,1992$.

28) Paul, A.: Chemical durability of glasses; a thermodynamical approach, J Mater Sci 12: 2246-2268, 1977.

29) Matsuya S, Ohta, M. and Fukazawa, M.: The erosion rate of carboxylate cement in acetic acid buffers, J Jpn Dent Mater 6(Spec Iss) : 116-117, 1987. (in Japanese)

30) Murakami, H., Matsuya, Y. and Matsuya, S.: Dissolution mechanism of zinc phosphate cement in acetic and lactic acid buffers, Biomater 11(8):435-440, 1990.

31) Japanese Patent S56-37964

32) Japanese Patent S52-5796.

33) Akashi, A., Matsuya, Y. and Akamine, A.: Water sorption characteristics of light-cured glassionomer cements, Japan J Conserv Dent 40(Autumn Iss) : 105, 1997. (in Japanese)

34) Matsuya, Y., Koda, M., Matsuya, S., Yamamoto, Y. and Yamane, M.: Erosion behavior of a zinc phosphate cement in dilute organic acid solutions, Dent Mater J 2:68-75, 1983.

35) Matsuya, S., Koda, M., Matsuya, Y., Yamamoto, Y. and Yamane, M.: Erosion process of polycarboxylate cements in organic acids, Dent Mater $J 2: 76-85,1983$. 


\title{
クエン酸緩衝液中における従来型および光重合型
}

\section{グラスアイオノマーセメントの侵食過程}

\author{
高 法章, 松家茂樹 ${ }^{1}$, 太田道雄 ${ }^{1}$, 張 建中 \\ 上海第二医科大学口腔医学院 \\ ${ }^{1}$ 九州大学歯学部㐘科理工学講座
}

本研究の目的は従来型および光重合型グラスアイオノ マー七メントの侵食過程を明らかにすることである。1 種類の光重合型および 2 種類の従来型グラスアイオノマー セメントを $\mathrm{pH} 4$ と $\mathrm{pH} 6$ のクエン酸緩衝液に浸せきし た.フッ素の溶出は $\mathrm{pH}$ に無関係に両タイプのセメント でほぼ同程度であった，他のイオン（Al， Sr，Si およ び $\left.\mathrm{P}_{2} \mathrm{O}_{5}\right)$ の溶出量は $\mathrm{pH} 4$ においては, 従来型よりも 光重合型のセメントの方が少なかった。しかし, $\mathrm{pH} 6$
においては光重合型セメントと従来型セメントの溶出量 は同程度であった. $\mathrm{pH} 4$ においては, 光重合型セメン トの溶解はセメントマトリックス中における溶出イオン の拡散によって律速された。一方, 従来型では拡散およ び表面でのマトリックスの分解反応が同時に進行した。 侵食後のセメント表面は上記の溶解過程に良く対応して いた. $\mathrm{pH} 6$ では, いずれのセメントも拡散が溶解を律 速していた.

\section{歯列模型解析システムの開発 \\ 一一歯列形態の 3 次元的診断および計測条件の検討一 \\ 若林一道, 荘村泰治 ${ }^{1}$, 高橋純造 ${ }^{1}$, 小島哲也, \\ 赤尾 剛, 中村隆志, 高島史男, 丸山剛郎 \\ 大阪大学歯学部歯科補緅学第一講座 \\ ${ }^{1}$ 大阪大学歯学部歯科理工学講座}

機能的かつ形態的に調和のとれた㐘や歯列弓を解析す るために，歯列模型の計測，咬頭頂のサーチおよび隅角 部における 3 次元座標の取得を行うシステムの開発を行っ た. 計測された歯列模型の詳細な形態は, サーフェスモ デルを用いた CGにより明確に表示された。

臼歯では咬頭頂の，犬歯では近遠心隅角部と尖頭頂の， 前歯では近遠心隅角部の 3 次元データを取得した後, 歯 列弓では 4 次関数を, 前後的および側方的咬合彎曲では
2 次関数をあてはめた. そして CGにより,これらの関 数を歯列模型のサーフェスモデルと同時表示した.

一方，咬頭頂の位置の誤差について，50 $\mu \mathrm{m}$ から400 $\mu \mathrm{m}$ まで計測ピッチを変えて検討した．計測ピッチを あげていくにつれ, 誤差も大きくなった. 計測誤差, 計 測時間およびデー夕量も考慮すると, 計測ピッチは 200 $\mu \mathrm{m}$ が最も効率的であることがわかった. 